Brazil. Above all, we need to maintain the actual freedom of research and freedom of methodology choice for research projects and research groups. The problem is that the evaluation can have a "washback effect": gradually, only research projects with chances to become funded are envisaged by the young faculty, and that can destroy that freedom in the future. Moreover, the new concern with imposing partially private funding can block interesting doctrinal research projects. Finally, allow me to express my personal point of view: only through tolerance, knowledge, and respect towards different countries, cultures and legal systems can we assure a productive and harmonic dialogue between jurists around the world. Knowledge is the path to development, and joint research is a very good way to create fruitful co-operations between Law Schools.

\section{Impasses do Direito Processual Civil Internacional do Mercosul e a oportunidade para o ReVIVAL das CIDIPs ${ }^{1}$}

\section{Augusto Jaeger Junior}

\section{Introdução}

Este artigo apontará os impasses enfrentados pelo processo de integração do Mercosul como um todo, a fragilidade do sistema de solução de controvérsias e da aplicação de suas normas e o oportuno momento para o reivial das Conferências Especializadas Interamericanas de Direito Intemacional Privado (CIDIPs).

\section{Os processos de codificação anteriores ao Mercosul}

Os processos de codificação na América começaram com o Congresso de Lima de $1877-1878^{3}$ e podem ser divididos em duas grandes fases: a primeira desejava uma codificação global do Direito Internacional Privado (DIP), na qual está inserida o Código de Bustamante, de $1928^{4}$, por exemplo, e a segunda descreve uma nova etapa aberta com o surgimento da Organização dos Estados Americanos (OEA), de codificação gradual e progressiva $a^{5}$. Elas podem ser aqui exemplificadas com os trabalhos dos Congressos de Montevidéu e com os das CIDIPs.

\subsection{Os Tratados de Montevidéu de 1889 e 1940}

Frustrada a participação de Estados americanos em congressos europeus para a codificação do direito internacional, tomou-se a iniciativa de convocar um congresso sulamericano. Assim, a convocação do Congresso de Montevidéu para o ano de 1889, por iniciativa de Argentina e Uruguai, determinou o apogeu do movimento codificador do Século 19 na América Latina. Essa convocatória representou uma manifesta contrariedade ao

\footnotetext{
Artigo escrito durante unna estadia de estudos na Justus-Liebig-Universitat Giessen, Alemanlia, em novembro de 2006, inserida no Projeto Conjunto de Pesquisa, Cooperação Científica e de Intercârnbio entre o Departannento de Direito Público e Grande do Sul Brasil e fin em 18 de novembro de 2006 na Deutsch-Lusitanische Juristen Vereinigung (DLJV), a convite dos Profs. Doutores Erik Jayme Christoph Benicke e Stefan Gnuldman, a quem agradeço.

Doutor em Direito do Mercosul e da Utinão Européia pela Universidade Federal do Rio Grande do Sul (UFRGS) Brasil Mestre em Direito Internacional pela Universidade Federal de Santa Catarina, Brasil. Professor da Faculdade de Direito da UFRGS em Porto Alegre, Brasil. Autor dos liv ros "Liberdade de Concorrência na União Européia e no Mercosul", "Mercosul e a livre circulaçâo de pessoas" e "Ternas de direito da integraçãao e comunitário", lançados pela Editora LTr, de São Paulo. Durante os anos de 2002 a 2005 foi bolsista do DAAD na Universidade de Heidelberg, Alemanhla junto ao prof. Dr. Dr.h.c. mult. Eril Jayme

FERNÁNDEZ ARROYO, Diego P. La codificación del Derecho internacional privado en América Latina, p. 90-95. Sobre esse importante Código ver FERNANDEZ ARROYO, Diego P. La codinícación del Derecho internacional privado en América Latina, p. 123-158 e SAMTLEBEN, Jürgen. Derecho Internacional Privado en Arnérica Latina: teoria y práctica del Código Bustamante, $399 \mathrm{p}$

5 FERNÁNDEZ ARROYO Diego P. La codificación del Derecho internacional privado en América Latina, p. 61-63.
} 
Tratado de Lima de 1878 e ao princípio da nacionalidade, sancionado por ele ${ }^{\varsigma}$. Internamente, o Congresso também serviu para que se conhecessem as posições contrapostas que existiam nessa época na América do Sul quanto ao ramo do direito internacional privado?

O não-consentimento do Brasil quanto a esse primeiro conjunto de tratados, que são oito no total, mais um protocolo adicional, foi devido ao fato de que eles descansavam no princípio do domicílio, promovendo uma virada em favor da concepção territorialista, que na época não era aceita no país. Os Tratados de 1889, ratificados pelos demais países da Bacia do Prata e outros, formam a primeira tentativa de codificação internacional de DIP a nivel mundial que alcançou uma vigência efetiva ${ }^{8}$.

Os Tratados de Montevidéu de 1940, resultados do Segundo Congresso Sulamericano, revisaram aqueles de 1889 e atualizaram os seus conteúdos por ocasião dos seus cinqüentenários. Ao todo foram firmados oito tratados e um protocolo adicional. Nem todos os países convidados, como era normal para a época, compareceram. As discussões reavivaram as opiniões opostas já existentes entre os participantes. O Brasil novamente declarou que o Tratado era incompatível com os princípios básicos de sua legislação e the negou consentimento ${ }^{\circ}$. Portanto, o Brasil não é parte dos Tratados de Montevidéu de 1889 e $1940^{\circ}$.

Como observa SAMTLEBEN, os efeitos dos Congressos de Montevidéu para o desenvolvimento do direito intemacional privado na América Latina foram de especial importância. Um aspecto a ressaltar é a difusão do princípio do domicílio na região ${ }^{11}$. No mesmo sentido FERNÁNDEZ ARROYO, para quem os tratados alcançaram uma aplicação quase cotidiana e se revelaram uma ferramenta útil para a regulação das relações de tráfego privado externo ${ }^{12}$.

\subsection{O trabalho da Organização dos Estados Americanos}

A criação da OEA na nona Conferência Panamericana, celebrada em Bogotá, em 1948, marcou um novo passo no movimento codificador da América ${ }^{13}$. A Carta da OEA adotou, no que difere da Carta da Organização das Nações Unidas, como objetivo expresso o desenvolvimento e a codificação do direito internacional privado. Alguns órgãos foram criados para essa finalidade específica. Hoje o órgão central para os trabalhos de codificação é

\footnotetext{
SARACHO CORNET, Teresita; DREYZIN DE KLOR, Adriana. Detecho Internacional Privado: Uma visión actualizada de

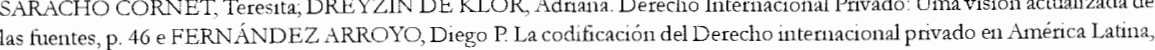
las fuentes, p. 46 e FERNANDEZ ARROYO, Diego P. La codificación del Derecho internacional privado en América Latina,
p. 97 .

SAMTLEBEN, Jurgen. Derecho Internacional Privado en América Latina: teoría y práctica del Código Bustamante, p. 15 ss. e FERNANDEZ RROYO, Diego P. La codificación del Derecho internacional privado en América Latuna, p. 102-116. las fuentes, $\mathrm{p}$.7 e FERN ÁNDEZ ARROYO, Diego P. La codificación del Detecho internacional privado en América Latina, las fuent 112

P. 112 .

v Ver a lista dos Tratados em DREYZIN DE KLOR, Adriana El Mercosur: Generador de una nueva fuente de derecho internacional privado, p. 240

" SAMTLEBEN, Jürgen. Derecho Internacional Privado en América Latina: teoria y práctica del Código Bustamante, p. 20 - FERNÁNDEZ ARROYO, Diego P. La codificación del Derecho internacional privado en América Latina, p. 121

SAMTLEBEN, Jürgerl. Derecho Internacional Privado en America Latina: teoria y practica del Código Bustamante, p. 35 ss. e FERNÁNDEZ ARROYO, Diego P. La codificación del Deiecho internacional privado en América Latina, p. 159-172
}

o Comitê Jurídico Interamericano.

Com o passar dos anos, a estrutura inicial da Carta da OEA se mostrou lenta para a satisfação do processo de codificação. Então, surgiu a idéia de vencer o marasmo e de dar novos impulsos ao movimento codificador com a convocação de CIDIPs ${ }^{14}$.

Assim, em 1971 a Assembléia Geral da OEA resolveu convocar uma conferência com aquelas características e propósitos ${ }^{15}$. A primeira reunião da CIDIP ocorreu no Panamá, em 1975. Nela foram assinados seis tratados. Ainda no mesmo ano, a Assembléia Geral da OEA resolveu convocar uma segunda conferência. Essa conferência aconteceu em 1979, em Montevidéu, e nela foram elaborados oito tratados. As reuniões seguintes foram celebradas em La Paz, novamente Uruguai, México e a última foi a de Washington, de 2002.

As Convenções Interamericanas de Direito Internacional Privado são em número de seis ${ }^{16}$ e resultaram em um novo direito intemacional que vem sendo definido em nível interamericano. Em suas sedes foram aprovadas importantes convenções que constituem um verdadeiro processo de codificação. Delas emergiram vinte e cinco textos internacionais ${ }^{17}$ que contribuíram decisivamente para a modernização do direito intemacional privado nos países. As concepções tradicionais em que se sustentava o DIP foram sendo modificadas de maneira perceptível. As relações jurídico-privadas adquiriram um marcado dinamismo ${ }^{18}$.

As CIDIPs revitalizaram o processo de codificação americano que estava contido desde a etapa das grandes codificações antes mencionadas ${ }^{19}$.

Nas conferências prosperou a idéia de serem formulados, de modo parcial e progressivo, convênios setoriais sobre temas específicos previamente identificados.

Como observam SARACHO CORNET e DREYZIN DE KLOR, em um primeiro momento houve um marcado predomínio de temas relativos ao direito processual civil internacional e ao direito comercial internacional. $O$ direito civil intemacional aparece na CIDIP III e vem a ganhar desenvoltura nas reuniões subseqüentes. Na CIDIP V o campo de legislação material foi notoriamente ampliado com a inclusão de temas de direito penal internacional. $\mathrm{Na}$ CIDIP VI se observou uma confirmação da troca do rumo que as atividades das CIDIPs vinham mantendo desde a sua criação e isso em relação especialmente a dois fatores: troca da técnica de regulamentação e modificação do procedimento de elaboração dos textos normativos ${ }^{20}$.

SAMTLEBEN, Jürgen. Derecho Internacional Privado en América Latina: teoria y práctica del Código Bustamante, p. 41 FERNÁNDEZ ARROYO, Diego P. La codificación del Derecho internacional privado en Anéérica Latina, p. 170 Conferir um balanço delas e as influências que tiveram nas fontes internas amenticanas em FERNANDEZ ARROYO, Diego P.; MASTRANGELO, Fabio (Orgs:). El futuro de la codificación del detecho internacional privado en América: De la CID IP VIa la CIDIP VII, p. 31-40 e 53-58 actualizada de las fuentes, p. 51-53. MASTRÁNGELO, Fabio. Presentaciónt. In. FERNÁNDEZ ARROYO, Diego P., MASTRÁNGELO, Fabio (Orgs.). El fưuro de la codificación del derecho internacional privado en América: De la CIDIP VI a la CIDIP VII $\mathrm{p}$ ?

SARACHO CORNET, Teresita; DREYZIN DE KLOR, Adriana. Detecho Internacional Privado: Umma visión actualizada de las fuentes, p. 49 e FERNÁNDEZ ARROYO, Diego P.; MASTRÁNGELO, Fabio (Orgs.). El futuro de la codificación del derecho internacional privado en América: De la CIDIP VI a la CIDIP VII, p. 8.

SARACHO CORNET, Teresita; DREYZIN DE KLOR, Adriana. Derecho Internacional Privado: Uma visión actualizada de las fuentes, p. 51 . 
As CIDIPs apresentaram, até a sua quarta ediç̧ão, um grande número de ratificações. Depois os temas se afastaram do DIP e elas ficaram mais espaçadas no tempo, de modo irritante, até ${ }^{21}$. Já as últimas não tiveram numerosas ratificações. A doutrina tem se referido à uma comercialização e privatização das CIDIPs, o que se vê refletido nas temáticas da CIDIP VII, e que quer dizer um deslocamento do eixo material da CIDIP para aspectos claramente enraizados no direito do comércio internacional, e um câmbio metodológico, com a passagem do predomínio da via convencional para a utilização de leis modelos ${ }^{22}$.

A partir dessa premissa, discute-se o futuro da codificação de direito internacional privado na América, com a reativação do processo interamericano para o suprimento das atuais necessidades de uma nova ordem jurídica continental, o que, inevitavelmente, passa pelas CIDIPs. Entende-se que a codificação continua sendo necessária, que o foro adcquado segue sendo a OEA e que, particularmente para a próxima Convenção, uma especial atenção deve ser prestada aos aspectos do direito intemacional privado dos contratos celebrados por consumidores.

O Brasil vem demonstrando, nos últimos tempos, uma profunda vocação integracionista com o continente pelo fato de ter ratificado várias CIDIPs ${ }^{23}$. Também, por outro lado, como lembra Opertti Badán, após seis CIDIPs muita coisa se alterou: os Estados Unidos da América passaram de uma posição refratária a uma posição participativa a partir da CIDIP V, o Mercosul emerge com o fenômeno da integração regional e começa a operar no campo do DIP e a dar respostas jurídicas aos problemas, essas nem sempre tecnicamente ajustadas ao processo codificador interamericano desenvolvido pelas CIDIPs, uma globalização de dimensões múltiplas irrompe e, por fim, observa-se o crescimento dos agentes privados na construção de uma nova ordem que responda a determinados interesses ${ }^{24}$.

No processo de codificação por etapas do DIP interamericano, levado a cabo pelas CIDIPs em seus documentos aprovados desde 1975, a área mais regulada foi a relativa às questões judiciais vinculadas aos casos privados internacionais. Várias convenções se referem a esses temas ou estão vinculadas a $\operatorname{eles}^{25}$. Afora isso a OEA elaborou até agora CIDIPs sobre letras de câmbio, cheques, cartas rogatórias, provas, mandato e representação, sociedades mercantis, laudos, medidas cautelares, prova e informação do direito estrangeiro, domicílio da pessoa física, normas gerais de DIP, adoção de menores, pessoa jurídica, jurisdição,

a FERNÁNDEZ ARROYO, Diego P.; MASTRÁNGELO, Fabio (Orgs). El futuro de la codificación del detecho internacional privado en América: De la CIDIP VI a la CIDIP VII, p. 59

FERNANDEZ ARROYO, Diego P; MASTRÁNGELO, Fabio (Otgs). El futuro de la codificación del derecho internacional privado en América: De la CIDIP VI a la CIDIP VII, p. 9-12

MARQUES, Cláudia Lima. Conflitos de convenções de processo civil interuacional: por um diálogo das fontes universais e regionais nos páses do Mercosul, p. 37. Confentr as Convençōes recentemente ratificadas em DREYZIN DE KLOR, Adnana
El Mercosur: Generador de una nulueva fuente de derecho internacional privado, p. 240, nota de rodapé 21, e em DREYZIN DE KLOR, Adriana. El derecho unternacional pivado en las relaciones Mercosur-Unión Europea, p. 1309, nota de rodape DE 19

* OPERTTI BADÁN, Didier. Palabras Introductórias. In FERNÁNDEZ ARROYO, Diego P. MASTRÁNGELO, Fabio (Orgs) El futuro de la codificación del derecho internacional privado en América: De la CIDIP VI a la CIDIP VII, p. 13-14.

s TELLECHEA BERGMAN, Eduardo La dimensión judicial del caso privado intemacional ..., p. 15 e em especial as mencionadas en VESCOVI, Eduardo. Problemas del proceso 'internacional' y cooperación jurídica internacional en los Estado mercosureños, p. $3^{7 / 4}-394$. alimentos, transporte intemacional, restituição de menores, contratos internacionais e tráfico de menores.

Várias delas vinculam os países do Mercosul ${ }^{26}$. Por esse motivo, há um certo consenso na doutrina quanto à desnecessidade e inoportunidade de o Mercosul refazer ou reelaborar em novos tratados os temas já trabalhados nas CIDIPs. Bastaria promover a ratificação e fomentar a utilização das CIDIPs por todos os Estados-partes do Mercosul ${ }^{27}$. Por exemplo, se alguma CIDIP tivesse previsto norma especial para o contrato de consumo internacional, uma convenção internacional no âmbito do Mercosul não seria necessária.

É justamente esta a lacuna que mereceu o estudo mais detalhado em toda a obra da Professora Doutora Cláudia Lima Marques, da Universidade Federal do Rio Grande do Sul, em Porto Alegre, Brasil, e é no que vai ser centrada grande parte desse artigo. A Convenção do México (CIDIP V) de 1994 sobre a lei aplicável aos contratos internacionais não chega nem mencionar a palavra consumidor ${ }^{28}$. Algumas regras indicadas para contemporizar essa situação não determinam uma efetiva proteção desse agente mais fraco. Não ter uma CIDIP tratado o tema representou uma oportunidade perdida, mas que pode ser recuperada com uma convenção especial. Por isso se fala em necessidade e oportunidade de a OEA elaborar uma convenção especializada sobre a proteção do consumidor, que estabeleça elementos de conexão e normas especiais para esse fim.

A autora citada, escorada na sólida doutrina alemã do grande mestre de Heidelberg Professor Erik Jayme, importou inúmeras teorias, estudadas e debatidas profundamente durante longos anos, e as aplicou em projetos de convenções internacionais e de modificações de leis brasileiras.

Inicialmente, a doutrinadora constatou a falta de uma proteção especial do consumidor nas normas de direito intemacional privado interamericanas e a conseqüente necessidade de uma convenção regional específica ${ }^{29}$. Ainda, que era chegado o momento para considerar, também nas normas de DIP elaboradas na OEA, a proteção do mais fraco na sociedade de consumo e de informação, o consumidor ${ }^{30}$.

Primeiro, perguntou-se se há uma lacuna legislativa no tema, que identificou apenas no que se refere aos contratos internacionais de consumo, com suas especificidades e suas normas nacionais de DIP antigas e falta de regras nas Convenções internacionais e mesmo leis modelos existentes. Depois, se seria oportuno elaborar uma convenção para preencher esta lacuna ou deixar a expansão da conexão da autonomia da vontade em contratos internacionais solucionar o problema naturalmente. $\mathrm{E}$ agregamos aqui que, devido aos atuais problemas enfrentados pelo Mercosul, que seria um outro foro convencional para o

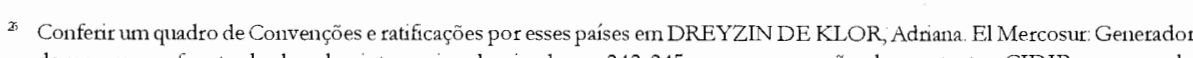
de una nueva fuente de derecho internacional privado, p. 242-245 e a compreensão de que tantas CIDIPs e regras do

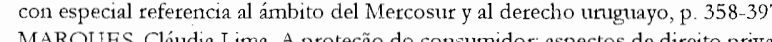

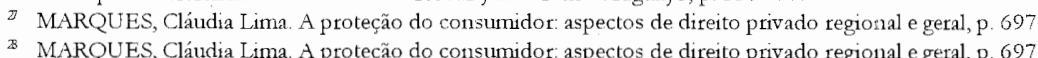

2 MARQUES, Cláudia Lima A protecáo do consumidor aspectos de diretto privado regronal e geral, p. 697. Cláudia Lima Confinaca no comércio eletrônico e a protecão do consumidor um estudo dos negócios juridicos de consumo no comércio eletrôninco, p. 341 e ss.

\. MARQUES, Cláudia Lima. A proteção do consumidor. aspectos de direito privado regronal e geral, p. 667 
trato da questão, o futuro da codificação do direito internacional privado na América passa pelo revival das CIDIPs.

De fato, determinadas situações ainda necessitam imperiosamente de uma regulação e o instrumento que a isso deve servir agora é o da CIDIP. Assim é a questão do direito aplicável ao comércio eletrônico e ao direito do consumidor, temas que são muito desenvolvidos pela obra da doutrinadora mencionada. O seu projeto de CIDIP sobre lei aplicável a alguns contratos e relações de consumo, ante à insuficiência da proteção dos consumidores nas normas de DIP, será levado à uma aberta discussão em breve. Há temas escolhidos pelo Conselho Permanente da OEA, como uma agenda para a CIDIP VII, e esses são a proteção ao consumidor e as garantias mobiliárias.

Paralelo ao surgimento e ao desenvolvimento do trabalho das CIDIPs nasceu o Mercosul e alterou a questão da cooperação jurisdicional, pois criou soluções comuns, paralelas às existentes, por tal apontadas como desnecessárias e inoportunas, que aprofundaram aquelas, fossem elas tratados universais, as próprias CIDIPs ou tratados sul-americanos multilaterais ou bilaterais. Os resultados dessa experiência do Mercosul, que em vários aspectos deu certo, como no da cooperação e assistência em direito internacional processual civil, serão vistos a seguir. $O$ processo de integração econômica enfrenta, todavia, vários problemas de outras ordens.

\section{O Mercosul e o surgimento de um direito processual civil internaciona}

Na constância do trabalho legislativo das CIDIPs, surgiu o Mercosul, que também passou a ser uma nova fonte de normas de direito internacional privado e de processo civil internacional. Com isso, um conflito de competências entre as organizações internacionais envolvidas foi explicitado, qual seja, o de saber como o trabalho do Mercosul, no âmbito da regulamentação do direito processual civil internacional, viria a se relacionar com as CIDIPs, especialmente pela constante afirmação da doutrina de que diversos temas receberem um duplo tratamento em ambas as instâncias. Afirma SAMTLEBEN que o surgimento de uma diversidade de blocos sul-americanos de integração diminuiu o interesse por uma unific ação das regras de conflito em âmbito continental. Para ele, isso ficou evidente com o pequeno número de ratificações que as novas Convenções passaram a receber ${ }^{31}$

Todavia, uma tal rivalidade já era conhecida pela doutrina desde longa data, especialmente no que se refere à convivência das Convenções Interamericanas com as Convenções de Haia, pois muitas das primeiras tiveram como modelo as segundas e mesmo outros acordos de ordem internacional ${ }^{32}$

A discussão no âmbito do Mercosul é a mesma, onde igualmente a solução não é fácil e nem o ambiente acadêmico estaria preparado para absorver essa quantidade de normas ${ }^{33}$.

Essa nova pluralidade de fontes em matéria de direito processual civil internacional foi também sentida e apontada como uma das características dos sistemas jurídicos

* SAMTLEBEN, Jürgen. Das Intemationale Prozeâ- und Privatrecht des MERCOSUR: ein Überblick, p. 60

$x$ SAMTLEBEN, Jurgen. Das Internationale Prozeà- und Privatreclıt des MERCOSUR: eil Überblick, p. 67

VESCOVI, Eduardo. Problemas del proceso internacional' y cooperación jurídica internacional en los Estados mercosureño p. 371-374 contemporâneos. MARQUES, em artigos em que se propõe a analisar como as convenções elaboradas pelo Mercosul podem ser harmonizadas ou coordenadas com outras convenções internacionais, observa que a solução desses conflitos não é mais dada pela aplic ação exclusiva de uma só das fontes, a monossolução, mas por meio de uma nova e complexa aplicação simultânea ou opcional, partindo da teoria do grande mestre Professor Erik Jayme, difundida através da expressão "diálogo de fontes" ${ }^{34}$. Segundo Erik Jayme, existem duas maneiras de resolver esses conflitos: a primeira consiste em dar primazia a uma das fontes, afastando a outra, aplicando uma certa hierarquia entre elas, e a segunda consiste em procurar a coordenação das fontes, através do diálogo delas ${ }^{35}$.

\subsection{O desenvolvimento e o estágio atual}

O fenômeno da integração econômica foi sentido também no Cone Sul, onde quatro páses formaram um bloco regional, o Mercosul, em 1991, através do Tratado de Assunção ${ }^{36}$ A cooperação econômica entre Brasil e Argentina da década de 80 foi vista como precursora desse processo ${ }^{37}$. O seu objetivo principal é a conformação de um mercado comum, de acordo com o exposto no artigo $1^{\circ}$. do Tratado. Essa é a fase que enseja a presença das liberdades fundamentais e a regulamentação de uma série de outros assuntos ${ }^{38}$. Para o seu alcance, $\mathrm{o}$ artigo $5^{\circ}$. do Tratado previu uma série de instrumentos ${ }^{39}$. $\mathrm{O}$ objetivo não foi atingido durante o período provisório, que tinha término previsto para 1994.

Esse não-alcance se tornou evidente com o surgimento do Protocolo de Ouro Preto, em $1994^{40}$, que implementou uma união aduaneira, uma vez que disciplinou as regras sobre a tarifa externa comum ${ }^{41}$. Com isso, foi considerado encerrado o período provisório ${ }^{42}$. A partir de sua vigência, o Mercosul passou a ter personalidade jurídica ${ }^{43}$. Este documento do direito primário sublinhou uma vez mais a opção por um caráter intergovernamental do processo, em que as decisões são tomadas por consenso e com a presença de todos os Estados-partes ${ }^{44}$. Esse caráter é o que representa a maior assimetria entre este processo e o da Comunidade Européia, sendo apontado como o principal impedimento à necessária execução

* MARQUES, Cláudia Lima. Procédure civile internationale et Mercosur. pour un dialogue des règles universelles et régionales, p. 465-484 e MARQUES, Cláudia Lima. Confititos de convenções de processo civil internacional por um diálogo das fontes universais e regionais nos países do Mercosul, p. 33-57

${ }^{5}$ JAYME, Erik. Identuté culturelle et intégration. le droit internacional privé postmoderne, p. 9-268

SALOMÃO FILHO, Calixto; SAMTLEBEN, Jürgen. Der Südamerikanische Gemeinsame Markt eine rechtilche Analyse des Mercosur (Teil I), p. 1345.

SALOMÃO FILHO, Calixto, SAM'TLEBEN, Jürgen. Der Südamerikanische Gemeinsame Markt eine rechtilche Analyse de Mercosur (Teil I), p. 1346.

SALOMÃO FILHO, Calixto; SAMTLEBEN, fürgen. Der Sudamerikanische Gemeinsame Markt eine rechtilche Analyse des Mercosur (Teil II), p. 1389

SALOMÃO FILHO, Calixto; SAMTLEBEN, Jürgen. Der Südamerikanische Gemeinsame Markt eine rechtilche Analyse des Mercosur (Teil I), p. 1350-1352

- SAMTLEBEN, Jürgen. Der Südamerikanische Gemeinsane Markt (MERCOSUR) und seine neue Verfassung, p. 1997 e ss. p. 129

Uma análise das reuniöes ocorridas durante esse periodo pode ser encontrada em SAMTLEBEN Jürgen. Der Südamenkikniscle Gemeinsame Markt (MERCOSUR) und seine neue Verfassung, p. 2000-2003

6 SAMTLEBEN, Jürgen. Der Südamerikanische Gemeinsame Markt (MERCOSUR) und seine neue Verfassung, p. 1997. * SALOMÃO FILHO, Calixto; SAMTLEBEN, Jurgen. Der Südamerikanische Gemeinsame Markt eine rech tilche Analyse des Mercosur (Teil II), p. 1385 e 1388. 
do direito da integração nos Estados-partes ${ }^{45}$. O Protocolo também criou novos órgãos e aumentou a responsabilidade dos que haviam sido criados pelo Tratado de Assunção. Como órgãos com poder de decisão, manteve e concretizou o Conselho do Mercado Comum, o Grupo Mercado Comum e a Comissão de Comércio do Mercosul ${ }^{46}$. O último órgão criado é o Tribunal Permanente de Revisão do Mercosul, pelo Protocolo de Olivos, instalado em $2004^{47}$.

O Mercosul gerou mais ganhos que qualquer organização anterior da qual fossem integrantes os seus Estados-partes. As relações de cooperação e de comércio foram expandidas. Até 1997 elas cresceram assustadoramente. Dispôs de uma condizente estrutur institucional ${ }^{48}$. Tornou-se um mercado interessante para os investidores estrangeiros ${ }^{2}$. A idéia de uma moeda única chegou a ser aviltada. Foi considerado um potencial competidor para a Comunidade Européia e para o Nafta. Nesse momento passou a ser visualizado um ordenamento jurídico no bloco, que conta com um direito processual civil internacional. Apesar do sucesso, o bloco enfrentou problemas.

Em 1999 os Estados-partes começaram a enfrentar crises econômicas que tiveram reflexos no Mercosul. Alguns instituíram cláusulas de salvaguarda, que desencadearam reações nos outros. Reveses políticos também foram computados. Tais fatos tornaram difíceis as relações entre os parceiros. A própria manutenção e o futuro da integração foram questionados. Com o agravamento da situação da economia argentina no final do ano de 2001, as expectativas de que o bloco viesse a se tornar um mercado comum diminuíram. É conhecida e difundida na doutrina a expressão de que ele palmilha uma região nebulosa entre uma zona de livre comércio ainda não totalmente implementada e os primeiros passos para o estabelecimento de uma união aduaneira.

Ante a essas crises, o processo conheceu idéias de relançamento, fundadas no fortalecimento institucional, na incorporação das normas emanadas dos órgãos do Mercosul pelos Estados-partes e na efetivação do sistema de solução de controvérsias. Desde 2002 Brasil e Argentina vinham reestabelecendo relações amistosas e cooperativas um com o outro e no contexto do Mercosul, para que os inúmeros ganhos adquiridos desde a sua fundação não fossem desperdiçados. Em 2004 novas desavenças comerciais se tomaram conhecidas sob o nome de Guerra das Geladeiras. Em 2006, o ingresso da Venezuela no bloco reativou alguns debates e esperanças.

\subsection{A Venezuela como membro pleno}

Em 2006, o grande tema da agenda do Mercosul foi a passagem da Venezuela de

6 VENTURA, Deisy. As assimetrias entre o Mercosul e a União Européa.a. os desafios de uma associaç̃o inter-regional, $694 \mathrm{p}$ Mercosur (Teii I), p. 1348-1350 e SAMTLEBEN, Jürgen. Der Südamenikanische Gemeinsame Markt (MERCOSUR) und sein neue Verfassumg, p. 1999-2000.

* PISCITELLO, Daniel Pavón; SCHMIDT, Jan Peter. Der EuGH als Vorbild: Erste Entscheidung des ständigen MercosurGerichts, p. 301-304 e SCHMID'T, Jan Peter. Neue Impulse durch institutionelle Reformen - der Mercosur ist wieder auf Kurs, p. 139-142.

SALOMÄO FILHO, Calixto, SAMTLEBEN, Jürgen Der Südamerikanische Gemensame Markt. ene techtrlche Analyse de Mercosur (Teil II), p. 1390

SAMTLEBEN, Jurgen. Der Südamerik anische Gemeinsame Markl (MERCOSUR) und seine neue Verfassung, p. 2005
Estado associado para Estado-parte do Mercosul, isto é, assumir a característica de membro pleno do processo. Com isso, ele passou a ter dez países entre essas duas modalidades de participação. O Tratado de Assunção, já em 1991, previu o ingresso de novos membros. Em sendo parte da Associação Latino-americana de Integração, fundada pelo Tratado de Montevidéu em 1980, a Venezuela preenchia uma condição importante para tanto.

A Venezuela é o quinto produtor de petróleo do mundo, sendo considerada uma potência energética. $O$ país tem vinte e sete milhões de consumidores/habitantes, quase um milhão de quilômetros quadrados, um Produto Interno Bruto respeitável de 1/7 do mesmo índice brasileiro. Com a Venezuela, o Produto Interno Bruto do Mercosul passaria para um trilhão de dólares, o que representaria 76 por cento do mesmo índice da América do Sul. Ademais, o país tem uma história integracionista muito rica, que passa pela personalidade do libertador Simón Bolívar, nascido em Caracas, em $1783^{50}$. Geograficamente, o seu ingresso permitiria a ligação do Caribe com a Patagônia. Enfim, tudo levava a crer que o ingresso desse novo país deveria ser efusivamente saudado.

Em verdade, o ingresso de um novo país é quase que como um dever imposto pela palavra integração e também por um processo como tal. Afinal, o Mercosul ganharia mais um membro pleno. Assim também se compreende da previsão da Constituição Federal brasileira de 1988 , que tem um parágrafo único no artigo $4^{\circ}$. com vistas à integração da América. E veja-se a União Européia que, com as incorporações de 2004, passou a ter vinte e cinco Estados-membros e outros são candidatos.

Mais, o ingresso da Venezuela representaria um novo freio à proposta norte-american de criação de uma Área de Livre Comércio das Américas, daria um forte alento ao processo do Mercosul, pois tratar-se-ia de um fato novo, retirando-o do certo marasmo em que se encontra, e seria uma alternativa para projetar um pouco mais a América do Sul no mundo.

E os problemas que poderiam ser gerados por conta do seu presidente Hugo Chávez, mesmo os externos, cuja conseqüência poderia vir a ser um estremecimento da relação da União Européia com o Mercosul, seriam resolvidos posteriormente. E não seria de bom grado um processo de integração e seus sócios condenarem um país a ficar fora do mesmo por causa do governante do momento.

Alguns argumentos temerosos quanto à entrada da Venezuela no bloco também foram evidenciados. Bastava tomar um jomal ou uma revista de política e eles eram facilmente vistos. Ainda que discritivel a existência ou não de uma democracia na Venezuela, certo é que o país é, agora, membro pleno do Mercosul.

\subsection{A solução de controvérsias}

Em função de obstáculos constitucionais e da opção pela intergovernabilidade, o mecanismo de solução de controvérsias assumiu uma característica diferente do existente na Comunidade Européia. O primeiro documento que regulou-o foi o Protocolo de Brasília, de 1991, de caráter transitório, que implantou um sistema arbitral.

Conferir os esforços de Bolivar para a codificação do DIP em FERNÁNDEZ ARROYO, Diego P La codificación del Derecho internacional privado en América Latina, p. 81-87 
As iniciativas tendentes a dar um impulso à integração envolveram a superação das deficiências derivadas da carência de um órgão que garantisse a interpretação uniforme do Tratado e tivesse capacidade para sancionar as violações às normas do Mercosul, a adaptação do sistema ao estágio atual da integração e a necessidade de fortalecer a estrutura institucional. Para tanto, em 2002 foi aprovado o Protocolo de Olivos. Ele entrou em vigor em 2004, derrogando o de Brasília.

Mesmo em meio aos períodos de crise, que desencadearam inúmeras medidas protecionistas e de represálias, o sistema de solução de controvérsias atingiu um relativo significado. As quatro primeiras controvérsias aceitas para ir ao tribunal arbitral ad hoc e que não resultaram em um acordo intermediário ${ }^{51}$ foram entre Brasil e Argentina. A primeira decisão do Tribunal Arbitral surgiu apenas em abril de $1999^{52}$. O segundo laudo arbitral ${ }^{5 .}$ surgiu no mesmo ano, cinco meses após o primeiro. Já no comeco de 2000 surgiu o terceiro laudo ${ }^{54}$. No ano de 2001 foram emitidos dois laudos arbitrais sobre conflitos em negociações comerciais ${ }^{55}$. Além desses, outros cinco se seguiram.

As iniciativas tendentes a dar um impulso à integração pretenderam superar as deficiências derivadas da carência de um órgão que garantisse a interpretação uniforme do Tratado e tivesse capacidade para constatar e sancionar as violações às disposições emanadas dos órgãos do Mercosul. Assim, uma decisão de 18 de fevereiro de 2002 aprovou o Protocolo de Olivos, que derrogou o Protocolo de Brasília e a Decisão n. 17/98 CMC, o seu regulamento de aplicação, de dezembro de 1998 . Ele entrou em vigor em $1^{\circ}$. de janeiro de 2004, juntamente com a Decisão n. 37/03 CMC, que é o seu regulamento de aplicação.

A possibilidade de recurso ao Tribunal Permanente de Revisão do Mercosul, segundo o artigo 17, instalado solenemente em 13 de agosto de 2004 e que tem como sede Assunção é o principal avanço em relação ao sistema estabelecido anteriormente ${ }^{56}$. Até então ọ sistema de solução de controvérsias não dispunha de instância recursal.

Outra inovação é a que consta do artigo $1^{\circ}$., n. 2, que faculta a submissão de controvérsias ao sistema de solução de controvérsias da $\mathrm{OMC}$ ou a outro sistema específico de comércio em que sejam partes individuais os Estados-partes do Mercosul. Este parágrafo também introduz uma vedação. Assim, uma vez iniciado um procedimento de solução de controvérsias de acordo com essa regra, nenhuma das partes poderá recorrer aos mecanismos estabelecidos nos outros foros, para a mesma questão. É o que se pode considerar a

ฐ Cerca de 450 consultas à Comissão de Comércio do Mercosul arningitam resultados satisfatórios e vieran a evitar o recurso ao procedimento arbitral. VENTURA, Deisy. As assimetrias entre o Mercosul e a Uniäo Européia os desafios de unra associação

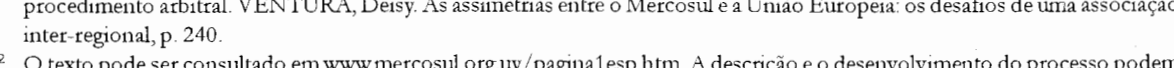

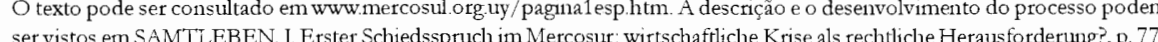
80 e mais resunido em LEHMANN, Julia. Neues von der chiedsgerichtstbarkeit des Mercosur: ein Integrationsmotor à Luxemburg? p. 623 .

\% O texto pode ser consultado em www.mercosul org.up/pagina1 esp.htm.

* O texto pode ser consultado em wwwmercosul.orguy/paginalesp.htm.

Os textos podem ser consultados em www.mercosul. org uy/ paginalesp htm.

PISCITELLO, Daniel Pavón; SCHMIDT, Jan Peter. Der EuGH als Vorbild: Erste Entscheidung des ständigen Mercosur Gerichts, p. 301-304 e SCHMIDT, Jan Peter. Neue Impulse durch institutionelle Reformen - der Mercosur ist wieder auf Kur: p. $139-142$. determinação da competência do órgão regional frente aos multilaterais por uma cláusula de eleição de foro.

Já o artigo $3^{\circ}$. se refere à novidade que possibilita ao Tribunal, mediante requisição dos Estados-partes, emitir opiniões consultivas sobre o direito da integração. Segundo ARAUJO, será nesta tarefa que o Tribunal "retomará o estilo, já consagrado nos laudos do Mercosul, de estabelecer o fio condutor da integração entre os textos normativos aprovados e a realidade diária que surge na sua aplicação",57. A expectativa é que o instrumento sirva a uma interpretação uniforme das regras do Mercosul e a uma confiança na sua arquitetura judicial.

Mais uma novidade a ser citada refere-se às fases do procedimento, já que as partes poderão passar das negociações diretas diretamente para o procedimento arbitral, sem, necessariamente, percorrer a fase que envolve o Grupo Mercado Comum, como o Protocolo de Brasília apresentava. Assim, segundo artigo $6^{\circ}$., a intervenção do Grupo passou a ser opcional.

Uma última característica é que o Tribunal de Apelação pode ser acionado diretamente depois da primeira fase do procedimento, isto é, depois das negociações diretas, mediante acordo, segundo o artigo 23. Nessa hipótese, os laudos serão igualmente obrigatórios, mas sem a possibilidade de recurso. De fato, o Tribunal tem como objetivo julgar os recursos de revisão dos laudos dos tribunais ad hoc apresentados pelos Estados-partes e também atuar como única instância a critério das partes em conflito, ditar medidas cautelares e de urgência e responder a consultas dos Estados.

O sistema, mais ainda o do Protocolo de Brasília, chegou a receber manifestações favorávers ${ }^{58}$. Críticas também não faltaram ${ }^{59}$. Dificilmente a doutrina o defende. Isso dá eco às manifestações de que o processo tem uma fragilidade institucional

\subsection{A fragilidade institucional}

Desde o surgimento do processo de integração, a doutrina tem indicado que o bloco poderia adotar um regime supranacional, com o que é esperada a solução de inúmeros problemas e um melhor enfrentamento dos períodos de crise. Segundo a opção feita pelo bloco, basta que um país discorde dos demais para que uma medida não seja adotada. A escolha pela supranacionalidade também envolveria um sistema efetivo de solução de controvérsias e um órgão para aplicar as decisões. A idéia da supranacionalidade não encontra aceitação nos governos e nem em outros círculos.

Em verdade, a ordem jurídica do Mercosul é invariavelmente tida como frágil. Não apenas o sistema de solução de controvérsias, mas a ordem jurídica como um todo recebe

5 ARAUJO, Nadia de. $O$ Tribunal Permanente de Revisẵo do Mercosul e as opiniōes consultivas: análise dos laudos arbitrais, sua ligação com a cornmon law e algunas idéias para o futuro, 28 p., que observa que o instrunnento recebeu franca inspiraçăo do reenvio prejudicial existente na Comunidade Européia

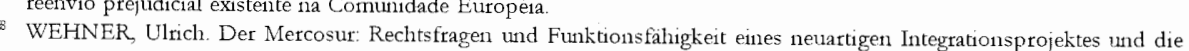
Erfolgsaussichten der interregionalen Kooperation mit der Europäischen Union, p. 110. Por JAYME foi apontada como um dos instrumentos para favorecer a integração em mercados como o Nafta : a Alca. JAYME, Erik. Identité culturelle et intégration: le droit internacional privé postmoderne, p. 70.

PORRATA-DORIA JUNIOR, Rafael A. Mercosur: the commom market of the twenty-first century? 
considerações. A fragilidade institucional e jurídica ${ }^{60}$ do Mercosul é quase incontestável ${ }^{61}$.

Essa estrutura frágil é ainda elemento de um dos paradoxos atuais do processo. Mesmo não tendo uma base jurídica sólida, o Mercosul já atua e mesmo legisla um modelo novo de direito ${ }^{62}$. Ocorre que da leitura do direito primário não fica claro se o Mercosul está ou não legitimado a impor estas leis nas ordens jurídicas internas e a controlar a sua execução, embora as normas sejam obrigatórias para os Estados-partes ${ }^{63}$.

Assim, cabe questionar como se legitimam os atos emanados dos órgãos do Mercosul. A aplicação das normas do Mercosul depende da constituição de cada Estado-parte ${ }^{64}$. Nem todas as constituições autorizam a transferência de competências às instituições. A isso há uma verdadeira aversão histórica. Nem as regras dispõem de princípios como o de primazia do direito da integração. Algumas doutrinas observam que pelo fato das normas do Mercosul necessitarem de concordância unânime dós Estados-partes, a elas deveria ser reconhecido efeito direto e imediato. Outras observam que o fato de o Mercosul poder praticar todos os atos necessários à realização de seus objetivos, segundo o artigo 35 do Protocolo de Ouro Preto, é o reconhecimento de alguma supranacionalidade ao Mercosul. Todavia, assim não ocorre. Uma norma do Mercosul só tem efeito depois que todas as partes tiverem adotado as medidas necessárias segundo as leis nacionais. Existe uma ampla tendência nos países de dar preferência à constituição nos casos de conflitos entre normas de direito internacional público e direito interno $0^{65}$. Ademais, a incorporação de normas não tem prazos definidos, ausência que aparenta ser o maior inimigo da normativa Mercosul, ainda que a Decisão n. 20/ 02 CMC busque prevenir o atraso da incorporação das normas do Mercosul.

Resumindo, a validade interna das normas depende da necessária concordância parlamentar e da publicação dos documentos. Com isso, tornam-se direito nacional e ainda diretamente aplicável. Todavia, as constituições são sempre supremas.

A conclusão é que a garantia de uma aplicação uniforme da ordem do Mercosul dentro dos Estados-partes é difícil. O direito do Mercosul não dispõe de uma dogmática comparável à comunitária, que envolve a primazia e a aplicabilidade direta do direito, bem como um cabedal jurisprudencial. Tais princípios não foram nem de forma expressa nem por outras medidas transportados ao Mercosul. Em função dessas ausências, sobretudo da

- Visōes da fragilidade instutucional podem ser vistas em MLARQUES, Cláudia Lima O 'Direito do Mercosul”': Direito oriundo do Mercosul, entre Direito Internacional Clássico e Novos Caminhos de Integração, p. 83-87 e em VENTURA, Deisy. As assimetrias entre o Mercosul e a União Européia os desafios de uma associação inter-regional, p. 108 e 589-601.

Ver uma contestação doutrinária estrangeira a essa constatação em JAEGER JUNIOR, Augusto. Liberdade de concorrència na Uniazão Européia e no Mercosul, p. 589

DREYZIN DE KLOR, Adriana. El Mercosur: Generador de una nueva fuente de derecho internacional privado, $395 \mathrm{p}$. fundamento de pedir no judiciário mas pelos quais se observa que o Supremo Tribunal Federal manteve a, tradič̃o dua como podarnerto de pedir Internacional Clássico e Novos Caminhos de Integração, p. $91-99$.

4 A questão da hierarquia das normas emanadas dos órgãos do Mercosul na órbita interna é esnidada em VENTURA. Deisy As assimetrias entre o Mercosul e a Uniãão Européia: os desafios de una associacão inter-regional, p. 167-223, pata quem os Estados-partes se dividem em potencialmente federalistas, sendo a Argentina o mais deles, e irreduliveis soberanistas, sendo o Unuguai o mais deles

SILVA, Elaine Ramos da. Rechtsangleichung im Mercosul: Perspektiven für das Niederlassungsrecht von Gesellschaften anlhand von Erfahrungen in der Europäischen Union, p. 48-49. supranacionalidade, é que não se pode falar de um direito comunitário do Mercosul. Do contrário não haveria uma separação doutrinária entre este e o direito da integração.

\subsection{O direito processual civil internacional do Mercosul}

Durante o período conhecido como de sucesso do Mercosul ${ }^{6,}$, mais ou menos situado entre o ano de 1995 e a eclosão da crise econômica argentina, já era possível afirma que o Mercosul possuía um ordenamento jurídico e hoje a doutrina já comenta acerca de uma constituição material ${ }^{67}$. O Tratado de Assunção, os protocolos de Ouro Preto e Brasilia, as decisões, resoluções e diretrizes formavam um ordenamento jurídico organizado e estruturado que possuía suas próprias fontes, dotado de órgãos e procedimentos aptos par emiti-las, interpretá-las, bem como para constatar e sancionar os casos de não-cumprimento e violações.

Para essa ordem jurídica é de grande relevância o que se pode considerar de processo civil internacional do $\mathrm{Mercosul}^{68}$. Os temas envolvidos são vistos como auxiliares para a solução dos conflitos de leis no espaço, ou matérias irmãs do direito internacional privado, hoje estando prática e pragmaticamente nele contidas ${ }^{6 \%}$. Conferências especiais interamericanas de direito internacional privado auxiliaram na formação dessa concepcão ${ }^{70}$. O Protocolo de Cooperação e Assistência Jurisdicional em Matéria Civil, Comercial, Trabalhista e Administrativa, chamado de Protocolo de Las Leñas, de 1992, regula a assistência jurisdicional e o reconhecimento e execução de sentenças e laudos arbitrais estrangeiros. O Protocolo de Buenos Aires sobre Jurisdição Internacional em Matéria Contratual de 1994 é outro documento que pode ser listado nessa ordem. Por fim, um processo do Mercosul ainda conta com o Protocolo de Medidas Cautelares, firmado em Ouro Preto, em 1994, com o Protocolo de Santa Maria sobre jurisdição internacional em matéria de relações de consumo e com o Protocolo de São Luis em matéria de responsabilidade civil emergente de acidentes de trânsito, ambos de 1996. Estes documentos sobre os litígios relativos às relações jusprivatistas internacionais no âmbito do Mercosul serão vistos agora.

Em uma determinada época, o Mercosul analisou se bastava recomendar a ratificação das CIDIPs para impulsionar a integração jurídica ou se era necessário tentar soluções de maior aproximação. Entendeu-se que as CIDIPs eram produto de um processo codificador

Caracterizado em JAEGER JUNIOR, Augusto Liberdade de concorrência na União Européia e no Mercosul, p. $560-564$ - DROMI SAN MARTINO, Laura. Derecho Constitucional de la Integración, p. 219-307.

* Tamberm chamado na doutrna argentina de direito internacional privado do Mercosul ou direto internacional privado institucional da integração. DREYZIN DE KL,OR, Adriana. El Mercosur: Genetador de una nueva fuente de derecho internacional privado, p. 246; MARQUES, Cláudia Lima. O “Direito do Mercosul": Diteito oriundo do Nercosul, entre Direito

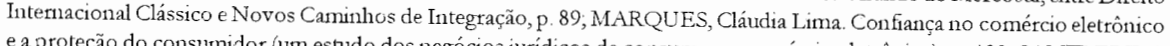
Jürgen. Die Entwickluntor des Internado dos negocios juridicos de consumo no comércio eletrònuco), p. 423; SAMTL.EBEN, Internationale Prozeâ- und Privattecht des MERCOSUR - ents im Mercosur, p. 376-383; SAMTLEBEN, Jürgen. Das Gerichtsstandsübereinkonnen für den Südameriton PABST, Haroldo. p. $76-79$ de consurno $n$ comércio eletrônico, 342 e DREYZIN De e a proteção do consumidor: um estudo dos negócios jurídicos Internacional Privado, p. 109-112

SAMTLEBEN, Jürgen. Das Internationale Prozeà- und Privatrecht des MERCOSUR: ein Überblick, p 9 
de relações privadas internacionais de escala continental, valiosas, mas que continham o abarcamento de realidades por vezes sensivelmente diversas, emergentes de páses pertencentes a sistemas jurídicos diferentes, localizados em uma extensa área geográfica estendida de um pólo ao outro. Por esse razão se concluiu que o Mercosul necessitava de regulamentações que avançassem mais que as interamericanas, aprofundassem os temas, ainda que envolvesse alguns já tratados por aquelas ${ }^{71}$ e sem que isso viesse a ser considerado um desperdício de esforços ${ }^{72}$.

Por isso, já foram firmados mais de treze acordos principais e complementares no âmbito do Mercosul quanto ao campo do direito aqui abordado ${ }^{73}$. Há um DIP do Mercosul ou então normas que são consideradas de processo civil internacional, segundo a doutrina dos países que o conformam ${ }^{74}$. Alguns protocolos trazem normas de DIP e outros tratam de processo e de normas auxiliares de DIP ${ }^{75}$. Em sua grande maioria são tratados de direito processual internacional e de cooperação judiciária. En não são inovadores em todas as suas partes. Observa RECHSTEINER que em muitos deles foram adotadas normas de tratados já existentes, principalmente as CIDIPs ${ }^{76}$.

O Protocolo de Las Leñas sobre cooperação e assistência jurisdicional em matéria civil, comercial, laboral e administrativa de 1992 trata do reconhecimento e execução de decisões e cooperação judicial intemacional. É considerado o documento mais fundamental para o tema entre os países do Mercosul ${ }^{77}$. Na doutrina estrangeira, esse documento recebeu comparações com normas européias ${ }^{78}$. Na classificação de TELLECHEA BERGMAN, representa um terceiro nível de cooperação jurídica internacional, qual seja o do reconhecimento da eficácia extraterritorial das sentenças ${ }^{79}$. Ele tem por finalidade facilitar as provas, as trocas de informações, o reconhecimento de sentenças e a cooperação em geral entre os Poderes Judiciários dos Estados-partes. Ainda, estabelece uma igualdade de trato processual com conteúdo amplo, incluindo a eliminação de barreiras e cauções para estrangeiros e pessoas jurídicas no Mercosul, e inova ao possibilitar os trâmites de reconhecimento e execução por carta rogatória ${ }^{80}$. Conforme o seu texto, o Protocolo inclui no Capítulo IV a cooperação em

I TELLECHEA BERGMAN, Eduardo. La dimensión judicial del caso privado internacional ..., p. 21 a DREYZIN DE KLOR, Adriana. Temas de Derecho de la Integración: Derecho Internacional Privado, p. 117 so Ver as mençôes em TELLECHEA BERGMAN, Eduardo. La dimensión judicial del caso privado internacional ..., p. 22. " MARQUES, Cláudia Lima O 'Diretto do Mercosul': Direito oriundo do Mercosul, entre Diretto Intemacional Clássico e Novos Caminhos de Integraçăo, p. 89, DREYZIN DE KLOR, Adriana. El Mercosur: Generador de una nueva fuente de derecho internacional privado, 395 p.; RECHSTEINER, Beat Walter Direito internacional privado: teoria e prática, p. 336 e ss.

Ver o tema em MARQUES, Cláudia Lima. Confiança no comércio eletrônico e a proteção do consunnidor: um estudo dos negócios jurídicos de consumo no comércio eletrônico, p. 423 e ss.

RECHSTEINER, Beat Walter. Diretto internacional privado: teoria e prática, p. 341

MARQUES, Cláudia Lima. Conflitos de convençôes de processo civil internacional: por um diálogo das fontes universais e regionais nos paises do Mercosul, $\mathrm{p}$. 4 .

PAMTLEBE

TELLECHEA BERGMAN, Eduardo. La dimensión judicial del caso privado internacional ..., p. 23.

DREYZIN DE KIOR, Adrana El Mercosur Generador de una nueva fuente de derecho internacional privado, p. 266 e ss, DREYZIN DE KLOR, Adriana. Temas de Derecho de la Integración: Derecho Internacional Privado. Córdoba: Advocatus 1998; PABST Haroldo. Das internationale Zivilprozeârecht des Mercosul, p. 77 e RECHSTEINER, Beat Walter. Direito internacional privado: teoria e prática, p. 341 e s. atividades de simples trâmite e probatórias, no Capítulo Vo reconhecimento e a execução de sentenças e laudos arbitrais e no Capítulo VII a informação de direito estrangeiro ${ }^{81}$. $O$ documento também trata de questões jurídicas gerais do direito processual civil internacional, mesmo que não vinculadas diretamente às questões de cooperação judiciária internacional, como a igualdade no tratamento processual e dos instrumentos públicos e outros documentos, como observa RECHSTEINER ${ }^{82}$. Está em vigor em todos os países do Mercosul. Foi influenciado fortemente por algumas $\mathrm{CIDIPs}^{83}$.

Esse documento e o mais adiante visto Protocolo de Ouro Preto tiveram a importante função de objetivar resolver o problema da divisão criada com os Tratados de Montevidéu e o Código de Bustamante entre o Brasil, de um lado, que não ratificou os primeiros, e o grupo formado por Argentina, Uruguai e Paraguai, do outro, bem como preencheram o vazio resultante da privação brasileira em relação às convenções interamericanas ${ }^{84}$.

O Protocolo de Buenos Aires sobre jurisdição intemacional em matéria contratual de 1994 significa um passo importante para a uniformização do direito processual civil internacional do Mercosul. Ele é aplicado à jurisdição contenciosa internacional com relação a contratos internacionais de natureza civil e comercial celebrados entre particulares, pessoas fisicas ou jurídicas. Então, são excluídas várias relações jurídicas, como, por exemplo, aquelas entre os falidos e seus credores e demais procedimentos análogos, especialmente as concordatas, a matéria tratada em acordos no âmbito de direito de família e das sucessões, os contratos de seguridade social e os administrativos, os contratos de trabalho, os contratos de venda ao consumidor, os contratos de transporte, os contratos de seguro e os direitos reais ${ }^{85}$. Outro requisito para a sua aplicação é que as partes do contrato tenham o seu domicílio ou sede social em diferentes Estados-partes do Tratado de Assunção ou que pelo menos uma das partes do contrato tenha o seu domicílio ou sede social em um Estado-parte e, além disso, que tenha sido feito um acordo de eleição de foro em favor de um juiz de um Estadoparte e exista uma conexão razoável, segundo as normas de jurisdição do Protocolo. Aproximase da Convenção de Bruxelas de $1968^{86}$ e permite a autonomia da vontade quanto à eleição do foro, uma eleição do foro expressa ou tácita e ainda a possibilidade de se submeter voluntariamente à arbitragem ${ }^{87}$. Está em vigor em todos os países integrantes do Mercosul.

O Protocolo de Ouro Preto de Medidas Cautelares de 1994 supôs a finalização do processo codificador do auxílio jurisdicional internacional entre os Estados-partes do Mercosul

s SAMTLEBEN, Jürgen. Das Internationale Prozeâ- und Privatrecht des MERCOSUR ein Uberblick, p 13-27. RECHSTEINER, Beat Walter. Direito internacional privado: teoria e prática, p. 343.

Ver as mençcōes em RECHSTEINER, Beat Walter Direito internacional privado: teoria e prática, p. 342 e 343, e em TELLECHEA BERGMAN, Eduardo. La dimensión judicial del caso privado internacional ..., P. 28-29.

MARQUES, Cláudia Lima. Procédure civile internationale et Mercosur: pour un dialogue des règles universelles et régionales, p. 465-484 e MARQUES, Cláudia Lima. Conflitos de convenções de processo civil internacional por unn diálogo das fontes * universais e regionais nos países do Mercosul, p. 49

Hercosur ein Überblick, p. 34 e $45-46$ e PABST, Haroldo. Das internationale Zivilprozeârecht des Mercosul, p. $77-79$.

* SAMTLEBEN, Jurgen. Das Internationale Prozeâ- und Privatrecht des MERCOSUR: ein Übetblick, p. $38-41$ ss. RECHSTEINER, Beat Walter Direito internacional privado teoria e fuente de derecho internacional privado, $p 281$ e Eduardo. La dimensión judicial del caso privado internacional ..., p. 75 e ss. 
e determina um nível de especial relevância para a cooperação cautelar. Ele implica na alteração de uma regra geral do direito brasileiro, qual seja a de que, para fins de homologação, uma medida cautelar proferida por um juiz ou tribunal estrangeiro é equiparada a uma sentença, isto é, necessita de homologação pelo Superior Tribunal de Justiça para que possa surtir efeitos jurídicos no Brasil ${ }^{88}$. Conforme o documento, não será mais necessária a homologação de medidas cautelares pelo Superior Tribunal de Justiça quando proferidas dentro de um Estado-parte do Mercosul ${ }^{89}$. A autoridade jurisdicional requerida, porém, poderá recusar o cumprimento de uma carta rogatória referente a medidas cautelares quando estas sejam manifestamente contrárias à sua ordem pública ${ }^{90}$. Está vigorando em todos os Estadospartes do Mercosul.

O Protocolo de São Luis em matéria de responsabilidade civil emergente de acidentes de trânsito de 1996 regula o foro e a lei aplicável à responsabilidade civil por acidente de trânsito e traz normas de DIP. Ele estabelece o direito aplicável e a jurisdição internacionalmente competente em casos de responsabilidade civil emergente de acidentes de trânsito ocorridos no território de um Estado-parte, nos quais participem, ou dos quais resultem atingidas, pessoas domiciliadas em outro Estado-parte ${ }^{91}$. O Protocolo está em vigor em todos os Estados-partes do Mercosul.

Por fim, o Protocolo de Santa Maria sobre jurisdição internacional em matéria de relações de consumo de 1996 é um protocolo específico que objetiva colmatar as lacunas deixadas pelo Protocolo de Buenos Aires de 1994. Para tanto, tem como objeto determinar a jurisdição internacional em matéria de relações de consumo derivadas de contratos em que um dos contratantes seja um consumidor ${ }^{92}$. Ele ainda não está em vigor nos Estados-partes ${ }^{93}$.

Há, pois, normas aprovadas e projetadas pelo Mercosul sobre direito do consumidor e consumo que, na expressão de MARQUES, é uma interessante legislação derivada de indireta proteção processual do consumidor ${ }^{94}$. A regra mais específica provavelmente seja o Protocolo de Santa Maria, por prever um regime especial de jurisdição mais protetivo dos consumidores nas suas relações contratuais no Mercosul. Ele recebeu até uma comparação com documentos estrangeiros pela doutrina alema $\tilde{a}^{95}$.

× SAMTLEBEN, Jürgen. Das Internationale Prozeâ- und Privatrecht des MERCOSUR: ein Überblick, p. 30; PABST, Haroldo. Das internationale Zivilprozeârecht des Mercosul, p. 79 e RECHSTEINER, Beat Walter. Direito internacional privado: teoria e prática, p. 362 e ss.

Ver como está a atual discussão sobre essa problemática em TELLECHEA BERGMAN, Eduardo. La cooperación jurisdiccional internacional con especial referencia al ámbito del Mercosut y al derecho unuguayo, p. 367

Para a definição desse conceito no Mercosul ver DREYZIN DE KLOR, Adriana. El Mercosur: Generador de una nueva fuente de derecho internacional privado, p. 323 e ss. $€$ DREYZIN DE KLOR, Adriana. Temas de Derecho de la Integración DAMTLEBEN, Ju Die E

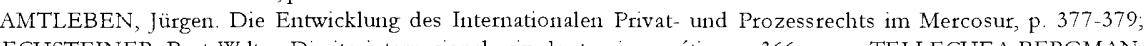
Direito internacional privado: teoria e prática, p. 366 e ss. e TELLECHEA BERGMAN, Eduardo. La dimensión udicial del caso privado internacional p 88 e ss

SAMTLEBEN, Jurgen. Das Internationale Prozeà- und Privatrecht des MERCOSUR: ein țberblick, p. 50-56 RICHTER, Thomas. Die rügelose Einlassung des Verbrauchers in Europäischen Zivilprozessrecht, p. $582-583$ eTELLECHEA BERGMAN Eduardo. La dimensión judicial del caso privado internacional .., p. $91-93$

\$ RICHTER, Thomas. Die rugelose Einlassung des Verbrauchers im Europäischen Zivilprozessrecht, p. 582

MARQUES, Cláudia Lima Confiança no comércio eletrônico e a proteção do consumidor um estudo dos negócios jurídicos de consumo no comercio eletrönico, $\mathrm{p} .428$

RICHTER, Thomas. Die rügelose Einlassung des Verbrauchers in Europäischen Zivilprozessrecht, p. 578-583.
Se ele e o Protocolo de Buenos Aires, este em vigor, fossem aplicáveis, ter-se-ia que o foro privilegiado do consumidor pessoa física seria o do seu domicílio, que o fornecedor deve acionar no país do domicílio do consumidor e que as cláusulas de eleição de foro seriam nulas, podendo o consumidor e somente ele, exclusivamente, ajuizar sua ação no Estado de celebração do contrato ou de cumprimento da prestação de serviço ou da entrega dos bens ou de domicílio do demandado-fornecedor, o que se poderia entender como um forum shopping a favor do consumidor ${ }^{96}$.

Este documento apresenta, todavia, conforme MARQUES, grandes falhas ou lacunas: a primeira é o fato de o Protocolo não se aplicar ao consumidor turista e a segunda refere-se à exclusão dele de todas as discussões envolvendo os contratos de transportes ${ }^{97}$. Outra falha apontada seria o seu campo meramente contratual, quando a doutrina vista aponta que a proteção do consumidor é também extracontratual, pré ou pós-contratual ${ }^{98}$.

Sobretudo, a entrada em vigor desse Protocolo é vista como problemática, em virtude de seu artigo 18, que diz que ele só entraria em vigor depois de terminados os trabalhos de unificação da Comissão de Comércio do Mercosul, isto é, quando findo o já superado trabalho para um Regulamento Comum de Defesa do Consumidor. Permanece, pois, esse útil e necessário Protocolo em um limbo jurídico. O seu futuro é incerto e a doutrina espera que o Mercosul possa solucionar esta situação de impasse e manifeste-se por normas especiais de proteção do consumidor ${ }^{99}$. Ademais, os tempos são de prevalência de normas materiais em casos internacionais, com a redução da importância do processo civil internacional tradicional ${ }^{100}$.

As crises do Mercosul e a dificuldade de aplicação das normas de processo civil internacional do bloco caracterizam a insuficiência da proteção do consumidor de forma processual e reforçam um revival das CIDIPs. O que se observou foi uma insuficiente opção pelo caminho do processo civil ${ }^{102}$ e uma unificação material impossível, como ainda se verá.

Já na Comunidade Européia, as normas de DIP e de processo civil internacional mereceram tratamento na Convenção de Roma de 1980, na Convenção de Bruxelas de 1968 e em uma série de atuais regulamentos comunitários. A Convenção de Roma de 1980 trata da lei aplicável aos contratos internacionais, inclusive os envolvendo os consumidores, tendo incluído norma específica que os privilegia. O sistema de DIP europeu se completa com as normas anteriores sobre uma jurisdição especial para o consumidor de 1968. Esta norma foi

o MARQUES, Cláudia Lima O inovo Direito intemacional privado e a proteção processual dos consumidores de bens e serviços estrangeiros ou no exterior, $\mathrm{P} .268$.

MARQUES, Claudia Lima Confiança no comércio eletrônico e a proteção do consumidor um estudo dos negócios jurídicos de consunno no comércio eletrônico, p. 433-435

MARQUES, Cláudia Lima. O novo Direito internacional privado e p proteção processual dos consumidores de bens e serviços MARQUES, Clí exterior, $p$. 289

de consumo no comércio eletrônico, p. 435 MARQUES, Cláudia Lima A Insuficiente proteç̃o do consumidor nas normas de DIPr: da necessidade de uma Convenção MASTRÁNGELO Fabio (Olcável a alguns contratos e relaçoes de consumo. In. FERNANDEZ ARROYO, Diego P; a la CIDIP VII, p. 124

in MARQUES, Cláudia Lima Confianç̧a no comércio eletrôninco e a proteção do consumidor: um estudo dos negócios jurídicos de consumo no comércio eletrônico, p. 405 e ss. 
elaborada verdadeiramente como uma convenção de direito internacional público clássico. A Convenção de Bruxelas já foi transformada no Regulamento n. 44/2001, em vigor desde 2002.

Como se observa, lá o assunto se apresenta mais desenvolvido. Desde 1960 era buscada a concretização de acordos que assegurassem aos cidadãos a simplificação de formalidades, as quais se subordinam o reconhecimento e a execução das decisões judiciais. Posteriormente, o Convênio de Bruxelas, de 27 de setembro de 1968, relativo à competência judicial e ao reconhecimento e execução de resoluções judiciais em matéria civil e mercantil, significou em seu momento um êxito político e um avanço inestimável no processo de unificação europeu ${ }^{102}$. Ele foi firmado pelos ministros de assuntos exteriores reunidos no seio do Conselho, com o que se pretendia afirmar seu caráter comunitário, configurando-se como convênio complementar ao Tratado de Roma. Entrou em vigor em $1^{\circ}$. de fevereiro de 1973. Esse documento não é considerado direito comunitário derivado e por tal não dispunha de efeito direto, nem de aplicabilidade imediata. No Protocolo de Luxemburgo de 3 de junho de 1971, os Estados consentiram submeter ao Tribunal de Justiça das Comunidades Européias a sua interpretação. Duas vias de acesso foram previstas, assim o recurso prejudicial de interpretação e o procedimento consultivo de interpretação ${ }^{103}$.

JAYME e KOHLER lembram que "A atividade legislativa da Comunidade (econômica) européia no domínio do direito privado é limitada desde longo tempo a aproximar, ou 'harmonizar' as regras 'materiais' dos direitos nacionais em setores determinados"104. Em que pese a Comunidade tenha ficado inativa longo tempo nessas questões, os Estados-membros concluíram entre si convênios internacionais em matéria de direito internacional privado, notavelmente o de Bruxelas e de Roma, sobre a lei aplicável às obrigações contratuais.

Esses acordos formam o núcleo do direito internacional privado e do direito internacional processual da Comunidade Européia ${ }^{105}$. Posteriormente, o papel do direito internacional privado como direito de integração (Integrationsrecht) da Comunidade Européia foi reforçado no TUE, com a introdução do princípio da subsidiariedade. Esse Tratado mantém e aperfeicoa o acervo comunitário, instaura âmbitos de cooperação intergovernamental nas áreas de política estrangeira e de segurança comum e nas áreas de justiça e de assuntos interiores. O direito internacional privado em si não figura entre as matérias pelas quais ele atribui competências à Comunidade. Apenas o artigo 293 TCE se refere ao reconhecimento e execução de decisões estrangeiras. Com o tempo, foi no setor da livre circulação de serviços que foram adotados os primeiros atos de direito derivado compreendendo regras de conflito ${ }^{106}$.

Em $1^{\circ}$. de março de 2002 entrou em vigor na Comunidade Européia o Regulamento

re JAYME, Erik. Identité culturelle et intégration: le droit internacional privé postmoderne, p. 66-67.

136 AUDIT, Bernard. Droit International Privé, p. 403

14 JAYME, Erik; KOHLER, Christian. L’interaction des règles de conflit contenues dans le droit dérivé de la Connmunauté européenne et des Conventions de Bruxelles et de Rome, p. 2.

${ }^{n}$ J JAYME, Erik; KOHLER, C. Das Internationale Privat- und Verfalirenssrecht der EG nach Maastricht, p. 346

Um rol de diretivas e regulamentos neste sentido pode ser visto em JAYME, Erik; KOHLER, C. L'interaction des règles de conflit contenues dans le droit dérivé de la Communauté européenne et des Conventions de Bruxelles et de Rome, p. 5-10 n. 44/2001 do Conselho, de 22 de dezembro de 2000 , relativo à competência judicial e à execução de resoluções judiciais em matéria civil e mercantil. O Regulamento, conhecido pela denominação de Bruxelas I, constitui um dos cinco atos normativos promulgados até então sob a competência do artigo 65 TCE, sobre a cooperação judicial em matéria civil. Veja-se que a realidade é bem outra.

\section{O revival das CIDIPs}

O revival das CIDIPs é devido a vários motivos. O primeiro aqui identificado foi a crise no Mercosul. Apesar do sucesso, o bloco passou a enfrentar nítidos problemas. Alguns foram vinculados à abertura econômica, redução do aparato do Estado e à evolução de problemas sociais como desemprego e miséria. Como lembra SALOMÃO FILHO, "processos de integração regional são dinâmicos - ou se desenvolvem de forma permanente ou tendem a uma involução. Os motivos para isso residem na dinâmica do comércio internacional (...). Tão logo o processo de integração se paralise, há a tendência do predomínio dos interesses particulares dos Estados e se opõem, em função disso, contra o comércio'107. Por isso é dito que a estagnação representa um retrocesso. Ainda que não seja tão visivel um retrocesso no processo do Mercosul, seguiu-se ao periodo de sucesso uma forte merco esclerosis $^{108}$.

Depois viriam os motivos econômicos, os sociais, os políticos, o fato de os países pararem quando há eleições. Também é possível de se pensar em uma imposiç̃o institucional, afinal a última CIDIP foi em 2002 e não se quer levar tanto tempo entre uma e outra como ocorreu entre essa e a de 1994.

Mas um revivaldas CIDIPs parece mesmo ser devido ao insucesso das harmonizações também das regras materiais de proteção ao consumidor no Mercosul e ao brilhante trabalho de sugestões legislativas que têm sido realizado por um grupo de doutrinadores interamericanos. Esses dois motivos serão melhor aprofundados.

\subsection{O insucesso da harmonização das regras materiais de proteção do consumidor no} Mercosul

Primeiro, vale fazer uma inserção na União Européia, onde a proteção do consumidor evoluiu para uma competência direta, proporcional e subsidiária para a defesa dos interesses dos consumidores com os Tratados de Maastricht e Amsterdam.

A atuação da União Européia como legisladora fez surgir um novo direito, cogente, supranacional, seja por meio de instrumentos de direito internacional público, como convenções e tratados, seja mediante instrumentos desse novo direito comunitário, como regulamentos e diretivas. Em verdade, ambos os grupos de instrumentos foram utilizados para impor novas normas e paradigmas de proteção ao consumidor.

Uf SALOMÃO FILHO, Calixto. Der MERCOSUL als Marktregelung. In: BASEDOW, Jürgen, SAMTLEBEN, Jürgen (Hrsg) Witschaftsrecht des MERCOSUR: Horizont 2000, p. 29-30.

In Em adaptação do termo euro esclerosis, relacionado às crises enfrentadas peia Comunidade Européia, utilizado em BIANCHI, Patrizio. Constrnir el mercado: Lecciones de la Unión Europea - el desarrollo de las instituciones y de las políticas de competitividad, p. 25 
Constata-se que desde 1975 até os dias atuais, com o atual artigo 153 do Tratado de Amsterdam, que considera a proteção do consumidor um dos objetivos políticos fundamentais da União Européia, a competência da mesma para legislar sobre a proteção do consumidor não deixou de crescer.

Tudo começou com o Primeiro Plano de Ação ou Programa Preliminar da CEE para uma Política de Proteção e Informação dos Consumidores, quando a então Comunidade assegurava a proteção do consumidor indiretamente pela garantia de uma concorrência leal. Os programas seguiram-se ${ }^{100}$ e geraram inúmeras normas materiais comunitárias harmonizadoras, através de regulamentos ou diretivas, que interessam aos consumidores ${ }^{110}$. Especialmente as diretivas criadas são diretivas mínimas, que estabelecem patamares mínimos comuns de defesa do consumidor, nunca patamares máximos ${ }^{111}$.

Em 1992, com o Tratado de Maastricht, a União Européia recebeu competência para estabelecer uma política de proteção do consumidor no bloco, todavia restringida pela aplicação do princípio da subsidiariedade ${ }^{112}$, mas que permitiu desde então ser conhecido um direito comunitário derivado material de proteção aos consumidores ${ }^{113}$.

As reformas propostas tendem a disciplinar que os fornecedores que oferecem produtos e serviços no mercado integrado para consumidores comunitários terão de se submeterem à jurisdição dos países dos respectivos consumidores. Assim, a integração econômica estaria assegurando a liberdade de vender e comercializar em toda a União Européia e as normas derivadas dos órgãos comunitários estariam indicando aos fornecedores os cuidados que terão que ter ${ }^{114}$

A doutrina ainda menciona a vigência de várias diretivas de proteção do consumido que trazem normas específicas de DIP, em especial as sobre cláusulas abusivas, time-sharing ou multipropriedade, contratação à distância, sobre garantias e sobre comércio eletrônico ${ }^{115}$.

Já no Mercosul, a efetivação das políticas de integração ocorre por meio de harmonização das legislações nacionais envolvidas. Esse processo não tem se apresentado fácil. Algumas matérias contaram com estudos e mesmo avanços. Outras não.

O tema da protecão do consumidor se desenvolveu apenas como uma propostainstitucional do Subgrupo 10 de Coordenação de Políticas Macroeconômicas, dentro do qual surgiu a Comissão

JAEGER JUNIOR, Augusto. Liberdade de concorrència na União Européia e no Mercosul, p. 241-248 e JAEGGER JUNIOR Augusto Temas de direito da integraçăo e comuntário, p. 215-21

Ver extenso rol de regras materiais comunitárias de proteção ao consumidot em MARQUES, Cláudia Lima. Confiança no comércio eletrônico e a ptoteção do consunidor: um estudo dos negócios jurídicos de consuno no comércio eletrônico, $\mathrm{p}$ 377 e 378 e em MARQUES, Claudia Lima. A proteção do consumidor: aspectos de direito privado regional e geral, p. 701-71 "I JAEGER JUNIOR, Augusto. Temas de direito da integraç̃ão e comunitário, p 218 e ss e JAEGER JUNIOR, Augusto. Liberdade de concorrencia na Uniao Europera e 1 to Mercosul, p. 70 e ss.

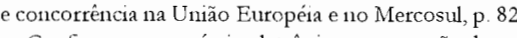

comércio eletrônico e a proteção do consumidor: um estudo dos

P. de consumo no comércio eletrôninco, p. 392-393.

"Ser os coneentários sobre todas essas normas em MARQUES, Cláudia Lima. Confianç̣a no comércio eletrônico e a protecão do consumidor: um estudo dos negócios juŕíicos de consumo no comércio eletrônico, p. 395-405 e um estudo espećf́ico sobre a diretiva cornunitánia em. matéria de responsabilidade decorrente dos produtos defeituosos em JAEGER JUNIOK Augusto. Temas de direito da integraç̃õo e comunitário, p. 213 e s. de Estudos de Direito do Consumidor, que, em 1994, foi substituída pelo Comitê Técnico 7 vinculado à Comissão de Comércio do Mercosul, órgão hoje responsável pela harmonização das regras sobre o tema. $\mathrm{O}$ que se observou foi uma unificação material impossível, que deve ser. analisada juntamente com a insuficiente opção pelo caminho do processo civil ${ }^{116}$, já vista.

Atualmente vive-se um grave esvaziamento dos trabalhos de harmonização das normas materiais realizado pelo Comitê Técnico 7. Mas as tentativas desse Comitê Técnico e os protocolos elaborados pela Reunião de Ministros de Justiça do Mercosul ${ }^{117}$ merecem uma citação e servem de base para a constatação da insuficiência da proteção do consumidor

Parte-se da premissa que o Mercosul falhou em estabelecer normas harmonizadas de defesa dos consumidores ${ }^{118}$. O processo de harmonização no Mercosul avança apenas pelo mecanismo do direito internacional público clássico, com tratados, protocolos, convenções e outras incorporações voluntárias das normas elaboradas pelos órgãos do bloco.

As tentativas de unificação e harmonização de normas materiais de proteção do consumidor no Mercosul foram frustradas. O tema do consumidor desenvolveu-se como uma proposta institucional ${ }^{119}$. A estrutura jurídico-institucional do Mercosul já foi apontada como frágil. O Mercosul não seria classificado como um processo de verdadeira integração e sim apenas como um processo inicial de integracão, o que estaria a afetar gravemente a sua possibilidade de legislar e impor uma legislação em matéria de direitos do consumidor. Não se trata de um processo verdadeiramente supranacional. A supranacionalidade que teria seria a menor possível, qual seja, a de existir! Os órgãos com capacidade decisória no Mercosul são formados exclusivamente por representantes dos governos dos Estados-partes. Os órgãos políticos de decisão do Mercosul também são dependentes das políticas nacionais, decidem por consenso e não têm maior autonomia

Mesmo assim, a doutrina se esforçou em encontrar uma competência legislativa sobre consumo em geral para o processo no sexto considerando do Tratado de Assunção, que estabelece a necessidade de modernização das economias nacionais, com a finalidade de melhorar as condições de vida dos habitantes desses países. Esta base, todavia, foi considerada muito ampla e pouco consistente. Uma outra base legal seria encontrada no artigo $1^{\circ}$. do Tratado de Assunção, que estabelece um compromisso geral de harmonização das normas nacionais em matérias essenciais ao processo de integração, considerado, por sua vez, dúbia ${ }^{120}$

Com esses fundamentos o Mercosul começou, em 1994, a legislar sobre a defesa do consumidor, instituindo normas materiais sobre uma variedade de aspectos do tema ${ }^{121}$.

16 MARQUES, Cláudia Lima Confialnça no coméscio eletrônico e a proteção do consumidor um estudo dos negócios jurídicos de consumo no comercio eletrònico, p. 405 e ss.

Sobre os trabalhos do órgão ver DREYZINDE KLOR, Adnana EI Mercosur: Generador de una nulueva huente de derecho internacion privado, p. 264 e ss. e TELLECHEA BERGMAN, Eduardo. La dimensión judicial del caso privado intemacional ..,p. 20-22 us MARQUES, Claudia Lima. Confiança no comércio eletrônico e a proteçãa do consumidor um estudo dos negócios jurídicos de consuno no comércio eletrônico, p. 405

10 MARQUES, Cláudia Lima. A proteçẫo do consunidor: aspectos de direito privado regional e geral p. $732-739$

MARQUES, Glada Lina Conn no comércio eletrônico e a proteção do consumidor um estudo dos negócios jurídicos Veras

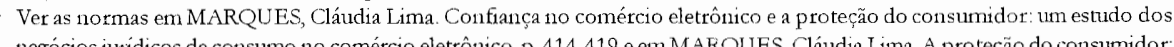
aspectos de direito privado regional e geral, $\mathrm{p}$.739-744 Sobre a a tividade legisiativa do Mercosul ver DREYZIN DE KLOR Adriana. El Mercosur: Generador de una nueva fuente de derecho internacional privado, $395 \mathrm{p}$. 
Essa legislação oriunda do Mercosul não é imediatamente coercitiva no plano interno. O próprio Tratado de Assunção reconhece essa falta de aplicabilidade das normas nos seus artigos 38 a 40 .

Segundo MARQUES, as regras materiais sobre a proteção do consumidor se dividem em dois tipos: aquelas que interessam apenas indiretamente à proteção do consumidor e que somente de forma reflexa significam uma preocupação do Mercosul com os consumidores e aquelas elaboradas pelo Comitê Técnico 7, em forma de resolução, para formar um corpo unitário de normas, que se denominaria Protocolo Comum de Defesa do Consumidor e que seria uma espécie de Código de Defesa do Consumidor do Mercosul ${ }^{122}$.

O projeto de Protocolo foi aprovado e assinado pelo Ministério da Justiça brasileiro, em 1997, mas foi recusado pela Delegação brasileira na Comissão de Comércio do Mercosul e considerado como um mero texto de trabalho, que não deveria ser colocado para a assinatura dos presidentes em dezembro do mesmo ano, pois poderia revogar cerca de vinte e sei artigos do Código de Defesa do Consumidor brasileiro ${ }^{123}$. Assim que foi superado e os esforços de harmonização recomeçaram em 1998, de forma tópica e limitada. Nos anos seguintes os temas não evoluíram sensivelmente.

Como não é possível dizer que o Mercosul apresenta um direito comunitário, nem referir-se ao seu ordenamento jurídico como direito comunitário do Mercosul, ao que seria necessário a supranacionalidade e um tribunal, uma efetivação das políticas de integração do Mercosul ocorre por meio de harmonização das legislações nacionais envolvidas. Ao não optarem pela construção do mercado comum com a supranacionalidade, tinham os Estadospartes consciência de que a integração dependeria da harmonização de suas legislações. Mecanismos de harmonização, neste contexto, não são demérito algum. Basta observar os efeitos da harmonização na Comunidade Européia.

Todavia, a harmonização legislativa no Mercosul, a qual tem a tarefa de apoiar a integração, não tem sido fácil, como já apontado. Os atuais problemas em termos de harmonização ${ }^{124}$ dizem respeito à ausência de normas nacionais a harmonizar, em alguns países, bem como às características bastante diferentes das leis editadas por outros.

Para a conclusão aqui proposta, impossível é não reportar a discussão tida com a tentativa de harmonização da proteção dos consumidores. A principal questão referiu-se combater a adoção de uma legislação que viesse a diminuir a proteção já garantida em alguns países, como Argentina e Brasil, com o Projeto de Protocolo de Defesa do Consumidor, de 29 de novembro de 1997 , e, do contrário, a elaborar um documento tópico e limitado que conduzisse o Uruguai e o Paraguai a apresentarem avanços no tema.

22 MARQUES, Cláudia Lima Confiança no comércio eletrônico e a proteção do consumidor um estudo dos negócios jurídico de consumo no comércio eletrônico, p. 415

MARQUES, Cláudia Lima Confiança no comércio eletrônico ea proceno do con Os promo no comertio eletronico, p. 420 .

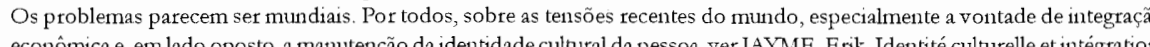

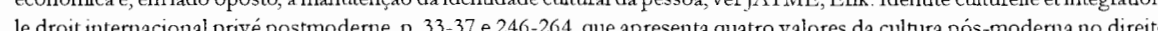
- pluralismo comunicacão, narracão e retour des sentiments, sendo o Leitmotive da pós-modertidade a valorizcõo do

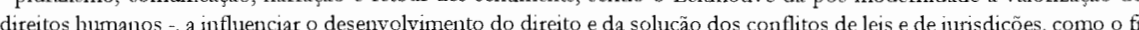
condutor da produção normativa contemporânea
Previsões de que o Mercosul seguisse o modelo da Comunidade e se tornasse um grande legislador para a proteção do consumidor foram feitas ainda durante o período provisório ${ }^{125}$.

Uma harmonização afastaria o viés da existência de legislação de proteção dos direitos do consumidor em uns países (vista como uma conquista social) e em outros não (desigualdade legislativa), que é a provável restrição à entrada e ao consumo de mercadorias e serviços oriundos dos países do mercado comum que não possuam igual nível de preocupação com a qualidade, informação e a segurança dos produtos, que é a extensão do limite à autonomia privada imposto ao nacional, em função da necessidade de adaptação às exigências legais.

Após o período provisório, quando a Argentina já possuía também uma legislação (Lei 24.240/93), o Mercosul foi novamente visto como legislador da proteção do consumidor, ainda que um poder geral de fazer leis não tivesse sido transferido pelo Tratado de Assunção nem pelo Protocolo de Ouro Preto. Este poder era, todavia, deduzido de uma competência considerada implícita na sua própria criação com finalidade integracionista (implied power, Kompetenz-Kompeten ). Uma harmonização sem consciência e discussão democrática, que não fosse baseada em pautas básicas e mínimas, no caso a que resultaria do projetado Regulamento comum de defesa do consumidor, poderia provocar o retrocesso e a destruição das duas garantias legais já conquistadas por Argentina e Brasil. A idéia era que a norma do Mercosul representasse um avanço nas legislações do Paraguai e Uruguai e não um retrocesso nas demais $^{126}$

O Projeto de Protocolo de Defesa do Consumidor, de 29 de novembro de 1997, foi posteriormente recusado pela delegação brasileira na Comissão de Comércio. Ele foi abandonado e os esforços recomeçaram em abril de 1998, de forma tópica e limitada. Depois disso o Mercosul não teve grandes desenvolvimentos em harmonização de regras materiais de proteção do consumidor.

Atualmente, Paraguai e Uruguai possuem as leis 1.334/98 e 17.250/2000, respectivamente, para o trato da proteção do consumidor. Toda essa normativa segue insuficiente para a proteção do consumidor no novo mercado sem fronteiras. Os esforços de harmonização das normas materiais no Mercosul enfrentam um impasse, para não usar a palavra fracasso.

\subsection{O trabalho dos doutrinadores interamericanos}

O revival das CIDIPs é também devido ao brilhante trabalho de doutrinadores interamericanos da atualidade, como Eduardo Tellechea Bergman, Diego P. Fernández Arroyo, Adriana Dreyzin de Klor, Nadia de Araujo e Cláudia Lima Marques, com suas propostas de Convenção.

${ }^{2}$ MARQUES, Cláudia Lima O Código Brasileito de Defesa do Consumidor e o MERCOSUL In: MARQUES, Cláudia Lima (Coord.). A proteção do consumidor no Brasil e no MERCOSUL, p. 107.

MARQUES, Cláudia Lima Regulamento comum de defesa do consumidot do Mercosul: primeiras observaçôes sobre o Mercosul como legislador da proteçăo do consumidor, p. 79-82. 
Os professores mencionados já declararam, sobre o futuro do processo da CIDIP, que a OEA segue sendo o foro adequado para desenvolver o processo de codificação do direito internacional privado nas Américas e que, nesse sentido, seria ideal uma certa permanência e especialização dos trabalhos nesse campo do direito dentro da Organização regional ${ }^{127}$.

A proteção internacional dos consumidores é hoje um dos temas mais atuais do DIP e MARQUES tem se dedicado seguidamente a ele, tanto no âmbito do Mercosul, como no interamericano. Assim, em 2000 lecionou no Curso da OEA sobre o tema, no Rio de Janeiro, cujo resultado foi uma sugestão de CIDIP sobre a lei aplicável a alguns contratos e relações de consumo. O Departamento do Direito Internacional da OEA já não tinha teito restrições a propostas de instituições que não formassem parte do Sistema Interamericano, nem dependessem de um Estado-parte, desde que fossem sérias e de qualidade, o que era o caso.

Em dezembro de 2003, o governo brasileiro, por sugestão de uma série de entidades e órgãos governamentais, sugeriu ao Comitê Jurídico Interamericano da OEA incluir o tema da proteção do consumidor no comércio eletrônico entre os temas a serem preparados para a próxima CIDIP. Com essa manifestação, a professora Cláudia Lima Marques propôs que o Comitê Jurídico Interamericano estudasse a conveniência de elaborar uma Convenção Interamericana de Direito Internacional Privado (CIDIP) sobre alguns contratos e transações com consumidores ${ }^{128}$.

Em 2004, a sugestão da doutrinadora foi aceita pelo Ministério da Justiça do governo brasileiro e enviada à OEA como sua proposta oficial para ser tema da CIDIP VII. Daí a OEA, em 2005, em Washington, definiu a sua agenda, tendo decidido que a proteção do consumidor seria um dos temas ${ }^{129}$ e que países de sociedades de consumo consolidadas, como o Canadá e os Estados Unidos da América, agregassem o tema da jurisdição ${ }^{130}$.

Cláudia Lima Marques apresentou uma proposta concreta e profunda, que reunia parte do seu conhecimento adquirido ao longo dos tempos de contato com a matéria e dos seus estudos internacionais, especialmente na Alemanha. Duas situações específicas foram contempladas por ela: a do consumidor-turista, assim aquele que se utiliza do sistema de multipropriedade ou time-sharing, e a do consumidor que contrata à distância, seja por meios tradicionais ou pelos novos meios eletrônicos.

Em resumo, em seus estudos desde 2000 sobre a protecão do consumidor em Direito Internacional Privado e na sugestão de CIDIP realizada, almeja propor uma utilização atualizadora do DIP, preenchendo estas normas normalmente instrumentais com valores sociais de proteção do parceiro contratual mais fraco, o consumidor, que oportunizarão a harmonia de relações internacionais necessária em nosso tempo, um DIP de solução material

v MARQUES, Cláudıa Lima. Confiança no comércio eletrònico e a proteção do consunindor: um esudo dos negócios jurídicos de consumo tio comércio elettồnico, p. 459

I8 MARQUES, Cláudia Lima A proteção do consumidor: aspectos de direito privado regional e geral, p. 667 O camunho para essa defíuç̧ão pode ser conferido em FERNANDEZ ARROYO, Diego P;; MASTRÁNGELO, Fabio (Orgs.) El futuro de la codificación del derecho internacional privado en América: De la CIDIP VI a la CIDIP VII, p. 66-69. * MARQUES, Cláudia Lima. $O$ novo Direito internacional privado e a proteç̃o processual dos consumudores de bens e serviços
estrangeiros ou no exterior, p. 293 . dos complexos conflitos pós-modemos, os quais agora envolvem direitos humanos e limites constitucionais, para que efetive a necessária proteção dos consumidores nos mercados internacionalizados dos dias de hoje.

A proposta brasileira de CIDIP VII, denominada de "Convenção Interamericana" (CIDIP) sobre a lei aplicável a alguns contratos e relações de consumo”, mas agora pelos delegados da OEA de "Proposta Lima Marques", consta de sete artigos e trata do problema da lei aplicável aos contratos internacionais com consumidores, incluindo os contratos concluídos por turistas, ou contratos à distância do comércio eletrônico (sem a presença fisica simultânea no mesmo local dos parceiros contratantes), os de pacotes de viagens e de multipropriedade ou time-sharing.

Em fevereiro e julho de 2005, a Assembléia Geral da OEA fixou o tema da proteção do consumidor, de acordo com a proposta brasileira, com o apoio do Canadá (com proposta própria de convenção ou de lei modelo sobre lei aplicável e sobre jurisdição em matéria de contratos do comércio eletrônico com consumidores) e dos Estados Unidos da América (com proposta da Federal Trade Commission sobre acesso à resolução de conflitos e devolução de quantias pagas pelos consumidores no comércio eletrônico).

Em março de 2006, iniciaram as negociações para a CIDIP VII, através de um foro eletrônico organizado pelo Departamento Jurídico da OEA, tendo como moderador John Wilson. Nestas discussões e em seus estudos de pós-doutorado em Heildelberg e nas discussões de seus seminários como Diretora de Estudos em Haia, em 2003, assim como nos congresso da Deutsch-Lusitanische Juristen Vereinigung, a professora Cláudia Lima Marques pôde evoluir muito o seu pensamento, o que lhe ajudou a modificar e aprimorar a sua proposta.

Temos a esperança que esta proposta de CIDIP VII consiga conciliar a pluralidade de métodos do direito internacional privado atual, com a tradição das CIDIPs e a vontade de evoluir na proteção do consumidor em matéria de conflitos, incentivar o crescimento do consumo internacional na região e ao mesmo tempo realizar os objetivos materiais de proteção da parte mais fraca, o consumidor, no crescente mercado interamericano de consumo.

A reunião preparatória ocorre em dezembro de 2006, em Porto Alegre, tendo a Faculdade de Direito da Universidade Federal do Rio Grande do Sul como local e sede. O objetivo da Reunião preparatória é proporcionar a continuação dos trabalhos para a CIDIP VII, cuja metodologia foi estabelecida pelo Conselho Permanente da OEA (ver documento CP/CAJP-2309/05) e descrita no Informe sobre o "Progreso de los Trabajos Preparativos para la Séptima Conferencia Especializada Interamericana sobre Derecho Internacional Privado".

$\mathrm{Na}$ reunião foram tratados os seguintes documentos de trabalho aprovados: a proposta dos Estados Unidos da América de uma "Lev Modelo sobre Mecanismos de Restitución Monetaria para Consumidores", a proposta do Brasil de uma "Convención Interamericana sobre la Ley Aplicable a Algunos Contratos y Relaciones de Consumo" e a proposta do Canadá de "una Ley Modelo sobre Jurisdicción y Reglas de Conflictos de Leyes para Contratos de Consumo".

A realização dessa reunião em Porto Alegre é uma homenagem, que aqui também 
rendo, aos longos anos de estudo, discussão e dedicação dessa brilhante professora e de seus mestres, em especial o professor de Heidelberg Erik Jayme, para essa causa, a quem também homenageio, por ter igualmente me conduzido nas minhas investigações por caminhos seguros.

Abschließend geht der Beitrag auf die wissenschaftlichen Initiativen der Jahre 2003 bis 2006 für die Durchführung einer siebten Interamerikanischen Konferenz für Internationales Privatrecht (CIDIPVII) ein. Diese hat den internationalen Verbraucherschutz zum Thema. Der Autor gelangt zu dem Schluss, dass heute ein günstiger Zeitpunkt ist, um dieses Thema im Rahmen einer Interamerikanischen Konferenz für Intemationales Privatrech zu behandeln. Dies liegt vor allem in den Schwierigkeiten begründet, denen sich der Mercosul im Moment stellen muss und in den Arbeiten anerkannter interamerikanischer Wissenschaftler, die gewissenhafte Vorschläge für die Kodifikation dieses 'Themas erarbeitet haben.

\section{Der Allgemeine Teil des brasilianischen Zivilgeseztbuchs: GeschichtLicher Hintergrund Und SYstematische ÜBERLEGUNGEN}

\section{Me. Lisiane Feiten Wingert Ody}

\section{Einführung: Thema und Gliederung}

Das Thema meines Vortrags ${ }^{2} 3$ ist der Allgemeine Teil des neuen brasilianischen Zivilgesetzbuchs.

Die erste Frage, die man sich stellen muss, lautet: Braucht ein Zivilgesetzbuch einen Allgemeinen Teil? Ist er notwendig? Ist er überflüssig? Oder ist er sogar schädlich? Dieses sind sehr interessante Fragen, die viel mit Methode und juristischer Ausbildung zu tun haben.

Das Thema des Allgemeinen Teils wurde in Brasilien sehr viel diskutiert. Das erste ZGB ${ }^{4}$ Brasiliens trat erst im Jahr 1917 in Kraft, und enthielt einen Allgemeinen Teil.

Wie Sie wissen, hat hier in Deutschland das $\mathrm{BGB}^{5}$ ebenfalls einen Allgemeinen Teil - der $A^{\top} T^{6}$ ist ein Erbe der Pandektistik, der in Europa auch Portugal und Griechland gefolgt sind. ${ }^{7}$ Aber wir wissen auch, dass andere Länder keinen Allgemeinen Teil haben, wie z. B. Frankreich, die Schweiz und Italien.

Die Kodifikationbewegung hat die europäische Rechtstradition tiefgreifend verändert: Frankreich, Deutschland, Italien, Spanien und Portugal sind Beispiele für Staaten, die sich eigene Zivilgesetzbücher schufen. Dadurch zerfiel die europäische Rechtseinheit, die bis dahin in Form des ius commune bestanden hatte. ${ }^{8}$ Für Brasilien war die Folge, dass sein Recht von vielen verschiedenen europäischen Iuändern beeinflusst wurde.

Dozentin (Professora Substituta) und Doktorandin an der Universidade Federal do Rio Grande do Sul (UFRGS) und Stipendiatin der CAPES an der Institut fuir auslandisches und internationales Privat- und Wirtsclaftsrecht der Ruprecht-Karls-Universitatit der CAPES an der Institut fuir ausländisches und internatione

Note der Autorin Der Text Professors Dr. Dr.l.c. Peter-Christian Müller-Graff, auf dem Gebiet des Europäische Graduirtenkoollegs Systent tinadung des und Wirtschaftsintegration im zusammenwachsenden Europa. Die Vortragc form wurde beibenalten mit sylen Vereinforchungen

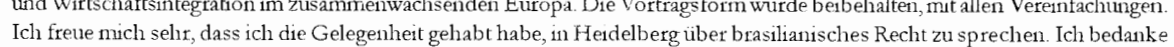
inich herzlich bei Professor Peter-Christian Miller-Graff für die Einladung, bei Professor. Thomas Pfeiffer, dafiir, dass er mich hier in Deutschland emp fangen hat, und bei allen alle Kollegen aus dem Institut für auslandisches und internationales Privatund Wirtschaftsrecht, die mich unterstiutzt haben. Icl möchte mich noch bein Max-Planck-Institut für ausländisches u. internationales Privatrecht in Hamburg bedanken, wo ich diesen Vortrag exarbeitet habe, und bei Herrn Jan Peter Schunidt, Referent für Latein Amerika, der mir bei der Vorbereirung dieses Vortrags geholfen hat. Besonders möchte ich mich bei Professor Erik Jayme bedanken, der mich an das deutsche Recht eingefihrt hat

Zivilgesetztbuch

bürgerliches Gesetzbuch

Allgemener Tell

ZTMMERMANN, Reinhard. The New German Law of Obligations: Historical and Comparative perspectives. Oxford Oxford University Press, 2005 s 5 ff Über das Thema, siehe: KÖTZ, Henn \& ZWEIGERT, Kontad Einführnung in die Rechtsvergleichung auf dem Gebiete des Phvatrechts. Tubingen. Mohr siebeck, 1996

Zuiversit Press 2005 ff uf den Gebete des 5 irat 